\author{
Małgorzata Mikołajczak \\ Wydział Humanistyczny \\ Uniwersytet Zielonogórski \\ e-mail: m.mikolajczak@ifp.uz.zgora.pl \\ ORCID: 0000-0002-7570-581X
}

\title{
Modelowanie regionu, przywracanie pamięci miejsca (Historie odzyskane Wojciecha Browarnego)
}

Dolny Śląsk jest dziś nie tylko jednym z najszybciej rozwijających się gospodarczo obszarów Polski, ale też regionem, który od roku 1989 przechodzi przyspieszony proces odzyskiwania lokalnej historii. $W$ tym procesie żywo uczestniczy twórczość literacka, będąca medium pamięci zbiorowej i świadectwem przeobrażania się regionalnej świadomości. Literatura stanowi zarazem szczególny zapis przemian dolnośląskiego społeczeństwa dając ich artystyczny obraz i diagnozę, sama staje się stymulatorem zmian i laboratorium wytwarzania lokalności. Jej wkład w powstawanie (i odzyskiwanie) tożsamości regionalnej jest niepodważalny. Przekonująco traktuje o tym książka Wojciecha Browarnego pt. Historie odzyskane. Literackie dziedzictwo Wrocławia i Dolnego Śląska, która ukazała się w roku ubiegłym jako 10 tom "Złotej Serii" Uniwersytetu Wrocławskiego ${ }^{1}$.

Autor książki należy do cenionych badaczy literatury współczesnej, jest również znawcą twórczości regionalnej i - jako kierownik Śląskiej Pracowni Regionalistycznej, działającej w Uniwersytecie Wrocławskim - z powodzeniem kontynuuje dzieło badania literatury i kultury dolnośląskiej, zainicjowane i prowadzone przez profesorów wrocławskiej polonistyki: Tadeusza Mikulskiego, Bogdana Zakrzewskiego, Jacka Kolbuszewskiego, Andrzeja Za-

\footnotetext{
1 W. Browarny, Historie odzyskane. Literackie dziedzictwo Wrocławia i Dolnego Śląska, Wrocław 2019. Zawarte w artykule cytaty pochodzą z tego wydania.
} 
wadę. Ma na tym polu znaczący dorobek, udokumentowany m.in. pracami powstałymi w ramach międzyuczelnianego projektu „Regionalizm w badaniach literackich - tradycja i nowe orientacje".

W swoich pracach regionalistycznych Browarny koncentruje się na problemach tożsamości, a omawiając teksty literackie wychodzi poza wąski krąg zjawisk estetycznych i czyta literaturę w kontekstach historycznych, kulturowych i społecznych. Tak dzieje się również w tym wypadku, przy czym Historie odzyskane to książka, która poszerza i wzbogaca dotychczasową perspektywę badawczą autora, jak również - co należy tu podkreślić - perspektywę badań nad literaturą dolnośląską w ogóle. Browarny proponuje w niej nowe, zarówno jeśli chodzi o poruszaną problematykę, jak i formułę badawczą, ujęcie spraw regionalnych, a jego zamysł można hasłowo określić w odwołaniu do takich pojęć ze słownika współczesnej humanistyki, jak nowy regionalizm, historia ratownicza, zwrot przestrzenny.

Tym, co w pierwszym rzędzie wyróżnia tę pozycję na tle innych prac poświęconych literaturze regionu, jest uprzywilejowanie parametru przestrzennego, które uwidacznia się już w układzie treści. Całością - kompozycyjnie przemyślaną, ujętą $\mathrm{w}$ ramy rozbudowanego wprowadzenia i podsumowania - rządzi podział wywiedziony z geografii. Poszczególne rozdziały noszą tytuły: Wrocław (Rozdział I), Śląsk (Rozdział II), Sudety (Rozdział III) i Łużyce Wschodnie (Rozdział IV). Tak zaprojektowana koncepcja współgra z sytuacją współczesnej literatury regionalnej, która za sprawą dokonującej się dziś reorientacji humanistyki (zainteresowania kwestiami geopoetyki i problemami peryferii) przemieszcza się z marginesu badań literackich ku ich centrum. Twórczość uprawiana na danym obszarze okazuje się dziś interesująca właśnie ze względu na zawarte $w$ niej deskrypcje miejsca - i głównie $z$ tej perspektywy (choć nie tylko) omawia ją autor, przyglądając się Wrocławowi Marka Krajewskiego, Ziemi Kłodzkiej Henryka Worcella i Karola Maliszewskiego, Świdnicy Władysława Grabskiego i Wojciecha Korycińskiego, a także ujęciom Wałbrzycha w powojennej publicystyce, sposobom rekonstrukcji Łużyc Wschodnich w pracach badaczy, pisarzy i regionalistów itp.

Pewnym problemem, z którego Browarny doskonale zdaje sobie sprawę, jest to, że nie wszystkie utwory stanowiące dziedzictwo literackie regionu wyróżniają się sygnaturą lokalną, nie wszystkie też poddają się regionalnej kategoryzacji, a dodatkowe komplikacje niesie ze sobą glokalizacja współczesnej kultury. Dlatego zrozumiała jest przestroga przed absolutyzowaniem regionalistycznej optyki, która może „trywializować teksty najbardziej abstrakcyjne i uniwersalne lub najbardziej osobiste, a przeceniać utwory, które podlegają schematom myślenia zbiorowego i dokumentalnego" [s. 184]. W tej sytuacji dobrym rozwiązaniem jest decyzja, aby lokalność wiązać nie tyle 
$\mathrm{z}$ geograficznymi realiami, ile $\mathrm{z}$ przetwarzaniem ich $\mathrm{w}$ kulturowe uniwersum znaków. Dzięki temu kompozycja książki zyskuje dodatkowe uprawomocnienie $w$ geografii wyobrażonej odnajdywanej $w$ tekstach. Jest przy tym podporządkowana celowi, jaki stawia sobie autor, a mianowicie "odzyskiwaniu historii" - stąd mamy tu nie tylko Wrocław, ale też Śląsk, Sudety i Łużyce Wschodnie.

„Odzyskać historię" to przywrócić pamięć historyczną miejsca, przechowywaną w małych, jednostkowych opowieściach, które istnieją niezależnie do „metahistorii”, jak za Haydenem White'm nazywa autor narrację narzucającą określony sposób rozumienia dziejów. Stratyfikacje przestrzenne, które powstają „w zaciszu politycznych gabinetów”, podobnie jak odgórne podziały administracyjne nie respektują, dowodzi Browarny, historycznych, geograficznych, kulturowych granic i dążą raczej do zatarcia regionalnej odmienności. Jest to szczególnie widoczne w przypadku Dolnego Śląska, będącego "Śląskiem właściwym”, o czym dziś mało kto pamięta - dlatego dobrze, że autor porusza ten problem. Nie tylko porusza, ale też inspiruje do dyskusji na ten temat, stwierdzając, że manipulacje takimi historycznymi pojęciami, jak Śląsk i Górny Śląsk:

doprowadziły do kuriozalnego przesunięcia obszaru tak nazwanego $\mathrm{w}$ przestrzeni geograficznej w stosunku do jego historycznego znaczenia i umiejscowienia $\mathrm{w}$ tejże przestrzeni. Śląskiem już $\mathrm{w}$ okresie międzywojennym zaczęto określać wschodnią część Górnego Śląska (później wraz z przylegającymi do niej obszarami Małopolski), a właściwy historyczny region o tej nazwie został po 1945 r. podzielony między Dolny Śląsk, Opolszczyznę, Wielkopolskę i Ziemię Lubuską [s. 123].

Wojciech Browarny upomina się o to, by przywrócić miejscom ich geograficznie, historycznie i kulturowo uzasadnioną nazwę, a jego postulatem jest powrót do wielowiekowej tradycji i związanej z nią regionalnej pamięci, która przetrwała pomimo wielokrotnego przesuwania granic i zmieniającej się przynależności państwowej. Dlatego rekonstruuje on zapomnianą kartografię i zgodnie z nią szeroko traktuje regionalne dziedzictwo. Obejmuje tym mianem zarówno literaturę powstającą na terenie dzisiejszego Dolnego Śląska, tj. administracyjnie wydzielonego województwa dolnośląskiego, jak również twórczość związaną z rozległym obszarem usytuowanym w przybliżeniu między Odrą, Nysą Łużycką i Sudetami, którego stolicą jest największa śląska metropolia - Wrocław. Na owo dziedzictwo składa się nie tylko literatura sensu stricte, wielorako (głównie poprzez temat i fabułę utworu, ale też przez miejsce powstania i opublikowania, biografię autora) związana z tym obszarem, ale i kultura literacka. 
Można by polemizować $\mathrm{z}$ takim ujęciem; bronić integralności Ziemi Lubuskiej, obstawać za lubuskością Zielonej Góry czy Żagania, co - muszę w tym miejscu wyznać - było moim pierwszym odruchem jako badaczki zajmującej się literaturą lubuską. Problem w tym, że nie ma tutaj dobrych argumentów, a różne racje okazują się bezradne wobec uzasadnień, za którymi stoi przywoływana przez autora pamięć kulturowa. Optyka proponowana w omawianej książce ma co najmniej cztery zalety. Po pierwsze, odrzucając narzucone stratyfikacje daje prymat temu, co jednostkowe, zindywidualizowane i co zdecydowanie lepiej przystaje do złożonej, niedającej się odgórnie kategoryzować kulturowej rzeczywistości. Dzięki temu - po drugie sprawdza się w praktyce badawczej: pozwala brać pod uwagę specyficzny dla tekstów literackich obszar wyobrażony o nieoczywistych granicach i zmiennej przynależności do krain historycznych i jednostek administracyjnych. Ma przy tym - po trzecie - charakter elastyczny i otwarty, umożliwia "regulowanie perspektywy", jak dzieje się to np. w rozdziale analizującym pisarstwo Karola Maliszewskiego. Najważniejsza jest jednak - po czwarte - otwierająca się w ten sposób możliwość odnajdywania zatartych ścieżek i znaków regionalnej pamięci.

Tytułowe „historie odzyskane” to opowieści, które tropią i oswajają ślady przeszłości Śląska - niemieckie, czeskie, łużyckie, morawskie, inne. To właśnie owe ślady stały się jednym $\mathrm{z}$ ważniejszych tematów literatury powstającej $w$ ciągu dwóch ostatnich dekad na terenach określanych po wojnie jako Ziemie Odzyskane. Teksty Olgi Tokarczuk, Andrzeja Sapkowskiego, Marka Krajewskiego, Henryka Wańka, Filipa Springera, Andrzeja Zawady, ale też mniej znanych, o których traktuje ta książka - Wojciecha Korycińskiego, Angeli Bajorek, Jörga Berniga i innych dekonstruują różne mity tożsamościowe, które pojawiały się po roku 1945, pokazują nawarstwione problemy, komplikacje i paradoksy regionalne. Odsłaniają przy tym i potwierdzają kulturotwórczy potencjał Śląska, który z mocą ujawnił się właśnie po roku 1989, gdy „różnorodność i pograniczność, wpisane w przeszłość regionu oraz społeczna otwartość jego mieszkańców zaczęły kształtować ich identyfikację zbiorową" [s. 132]. Dlatego właśnie w centrum zainteresowania autora znalazła się literatura ostatniego dziesięciolecia XX wieku oraz powstająca już w nowym stuleciu, tej twórczości poświęca on najwięcej uwagi.

Jego ujęcie ma jednak również i tę wartość, że nie zamyka się w rozważaniach na temat najnowszych utworów i proponuje też relekturę tych, które powstawały wcześniej. Z perspektywy „odzyskanych historii” można dostrzec niedoczytane sensy tekstów wychodzących po roku 1945, a także ich związki z procesem tożsamościotwórczym - autor śledzi je m.in. w roz- 
działach zatytułowanych Laboratorium "Ziem Odzyskanych". Literatura i wrocławska tożsamość po 1945 roku, Sudety w literaturze polskiej po drugiej wojnie światowej, a także w rozdziale dotyczącym powieści historycznych Władysława Grabskiego, które odczytuje jako "geopolityczną instrukcję do rozwiązywania problemów «Ziem Odzyskanych»". To właśnie ukierunkowanie poznawcze jest jednym ze wspomnianych na początku wyróżników książki. Przyglądając się regionalnemu piśmiennictwu Wojciech Browarny kładzie nacisk na obecne w nim sposoby konstruowania narracji tożsamościowej, przede wszystkim na uwarunkowania, mechanizmy, reguły konstrukcyjne narracji piastowskiej i myśli zachodniej. Badając je sięga m.in. do esejów Stanisława Kolbuszewskiego (Dojrzewanie narracji "Ziem Odzyskanych". Battyckie eseje Stanisława Kolbuszewskiego), które - mimo że dotyczą tytułowych stolic państw bałtyckich - reprezentują strategię narracyjną analogiczną do myśli zachodniej; ich lektura pozwala wskazać korzenie powojennej opowieści o Śląsku, odnaleźć jej romantyczne i modernistyczne składniki. Pod tym kątem - pytając o współczesną pamięć zbiorową i metahistorię nadającą współczesnym opowieściom autentyzm, wiarygodność, komunikatywność i perswazyjność - Browarny czyta też utwory współczesne, m.in. cztery książki: autorstwa Andrzeja Zawady, Filipa Springera, Tomasza Rzeczyckiego, Henryka Wańka, poświęcone w znacznej części tematyce sudeckiej. Różnią się one pod względem sposobu wyjaśniania, struktury fabularnej, formy gatunkowej i języka narracji metahistorycznych, we wszystkich jednak Sudety traktowane są jako wspólne dziedzictwo wielu narodów i złożona geograficzno-kulturowa całość, która - mimo że nie przetrwała do naszych czasów - pozostawiła po sobie ślady, pozwalające ją odkrywać i projektować ponownie.

Uruchomienie regionalistycznej perspektywy okazuje się płodne poznawczo w przypadku literatury, która dotąd była czytana bez udziału klucza regionalnego. Dotyczy to m.in. utworów Tadeusza Różewicza, które wbrew obiegowym sądom, głoszącym, że poeta programowo nie interesował się regionem, okazują się mocno związane z miejscem. W rozdziale Tadeusz Różewicz jako zmarly (pogrzeb i miejsce spoczynku pisarza) Browarny przekonująco dowodzi, że poprzez decyzję, by zostać pochowanym w ziemi karkonoskiej na cmentarzu ewangelickim, poeta celowo dokonał interpretacji własnej biografii i dzieła, uczynił się niejako „przodkiem” ludzi pogranicza. Ów gest stał się dopełnieniem innego zamysłu autobiograficznego, tj. decyzji poety o osiedleniu się we Wrocławiu. Pisząc o tym w rozdziale Miasto otwarte. Tadeusz Różewicz i neoawangardowy Wrocław na przełomie lat sześćdziesiątych $i$ siedemdziesiatych $X X$ wieku autor stawia interesującą hipotezę - twierdzi mianowicie, że zamieszkanie Różewicza w mieście palimpsestowym i pery- 
feryjnym, pozbawionym lokalnej pamięci zbiorowej i zasiedziałej, zintegrowanej społeczności wiąże się $\mathrm{z}$ metapoetycką koncepcją człowieka $\mathrm{w}$ jego utworach i z charakterystycznym dlań przekonaniem, że biografia nie może nigdy się złożyć w spójną całość. Takich interpretacji, rzucających nowe światło na literaturę powstającą na Dolnym Śląsku, objaśniających mechanizmy jej powstawania, ale też popularności (przypadek kryminałów Marka Krajewskiego) jest tu więcej. Rozpoznania Browarnego są przy tym nie tylko świeże i odkrywcze, ale też świetnie podane - napisane przystępnym językiem, dobrze uargumentowane, merytorycznie przekonujące i, co warto podkreślić, ciekawe.

Walorem książki jest szerokie, wieloaspektowe ujęcie tytułowego dziedzictwa. Autora interesuje bowiem nie tylko tzw. literatura piękna, ale też reportaż (Włodzimierza Nowaka, Filipa Springera), esej (Stanisława Kolbuszewskiego, Henryka Wańka, Andrzeja Zawady), szkice historyczno-krajoznawcze (Stanisława Rzeczyckiego), a także teksty naukowe i publicystyczne, omawiane w obszernych rozdziałach zatytułowanych Łużyce Wschodnie w polskich pracach krajoznawczych i prasie regionalnej po 1970 roku. Zarys dziejów pojęcia oraz Wałbrzych "non-fiction"? Reportaże o tematyce wałbrzyskiej na tamach tygodników "Nowe Sygnały" $i$ "Odra". Przedmiotem refleksji jest tu wielogłosowa narracja, regionalny polilog, w którym na równych prawach uczestniczy literatura piękna i literatura faktu, twórczość niska i wysoka, ambitna i popularna. Ta ostatnia - co potwierdzają zawarte tu rozpoznania na temat kryminałów Marka Krajewskiego i Wojciecha Korycińskiego - z powodzeniem przejmuje dziś funkcję narracji tożsamościotwórczej, staje się przewodnikiem po regionie, kreuje nowe mity miejsca i odpowiada na potrzeby lokalnej wspólnoty.

Szczególnie interesujące refleksje wywiedzione zostały z lektury książek Andrzeja Zawady (Bresław, Drugi Bresław, Dolny Śląsk. Ziemia spotkania), które - jak to określa Browarny - stanowią "zadanie domowe" dla mieszkańców Wrocławia i są zachętą do stworzenia nowej kulturowej tożsamości. O autorze też można by powiedzieć, że idzie szlakiem wyznaczonym przez wrocławskiego profesora. I mimo że inaczej rozkłada akcenty swej narracji regionalnej, to podobnie jak twórca Bresławia jest rzecznikiem odzyskiwania pamięci i tradycji regionalnej. Przyświeca mu też podobny cel: rozumienie zjawisk kulturowych poprzez literaturę traktowaną jako medium, które wszechstronnie i wnikliwie oddaje rzeczywistość społeczną. $Z$ takiego nastawienia wynika formuła książki, która nie jest typową naukową monografią. Novum tej propozycji polega m.in. na tym, że omawiając zróżnicowane gatunkowo piśmiennictwo regionalne (prozę, poezję, eseje, teksty publicystyczne i prace naukowe), sama też sięga po różne formy opisu. 
Autor świadomie operuje ruchomą perspektywą, budując bądź skracając dystans. „O prozie dolnośląskiej piszę zatem trochę w konwencji historycznej, niektóre utwory analizuję krytycznie, a inne czytam z perspektywy lokalności jako mojej, najbliższej przestrzeni kulturalnej" [s. 183] - stwierdza. W jego pracy dominuje ta ostatnia perspektywa, wybrana ze świadomością, że „pisząc o kulturze swojego miasta i regionu trudno zachować obiektywizm, oddzielić postawę badacza od sytuacji uczestnika, rozgraniczyć historię i osobistą pamięć, przedstawić miejscowe doświadczenie z dystansem" [s. 183]. $\mathrm{W}$ ten sposób Browarny łączy kompetencje wytrawnego krytyka, badacza i regionalisty, a przy tym odświeża dyskurs regionalistyczny - uprawiając, jak czytamy w autodeklaracji:

regionalizm refleksji, polilogu i zaangażowania, czuły na opowieści kłopotliwe, subwersywne, odrzucone, zapomniane, uznawane wcześniej za nieważne lub obce, projektujący region wyobrażony, w którym te nieoczywiste narracje są na swoim miejscu, okazują się potrzebne i zrozumiałe, tłumaczą ludziom najbliższy świat oraz łączą z tymi, którzy zamieszkiwali go wcześniej i opowiadali o nim inaczej [s. 342].

Takie nastawienie sprawia, że autor książki wchodzi w inną jeszcze (ważną społecznie) rolę - rzecznika regionalnej społeczności. Można by o nim powiedzieć, że jest badaczem intelektualistą w rozumieniu Edwarda Saida, wspierającym opór peryferii wobec centrum i stającym po stronie narracji alternatywnych wobec oficjalnej pamięci i oficjalnej tożsamości; dążącym do tego, by demaskować język "centrum” i rozbrajać narracje zawłaszczające. Jako przedstawiciel marginalizowanej mniejszości domaga się rewindykacji utraconych znaczeń śląskości, dopomina się o miejsce dla Łużyc Wschodnich na mapie polskich regionalizmów, oręduje za przywróceniem Wrocławiowi statusu miasta, które przez wieki było śląską metropolią, centrum gospodarczym i kulturowym Śląska, natomiast w XX wieku utraciło tę rangę. Wrocław, zauważa Browarny, nie miał większego znaczenia ani dla przedwojennej niemieckiej, ani dla powojennej polskiej geopolityki. Zwłaszcza po roku 1945 uznano to miasto za niewiele znaczące dla polskiej kultury, głównie ze względu na jego niemieckie dziedzictwo. To dziedzictwo starano się zatrzeć za pomocą działań repolonizacyjnych, $w$ tym narracji piastowskiej oraz polityki unifikacyjnej, dążącej do ujednolicenia regionu różnorodnego narodowo, kulturowo, religijnie. Towarzyszyła temu rabunkowa polityka, polegająca na ograbianiu Wrocławia z różnego rodzaju dóbr materialnych, a także na pozbawianiu go odrębnej tożsamości i dziedzictwa kulturowego. Autor książki postrzega ten proces w kategoriach wewnętrznej kolonizacji, sięgając po termin wprowadzony do polskich badań nad zależ- 
nościami centralno-peryferyjnymi przez Tomasza Zaryckiego; i choć można by dyskutować z tym ujęciem, to nie sposób zaprzeczyć, że po wojnie stolica Dolnego Śląska miała status półperyferii podporządkowanej metropolii - Warszawie. Tę zależność obrazują interesujące rozpoznania zawarte w podrozdziałach Dlaczego Warszawa? Topos poczattu i Geopoetyka odbudowy - pokazują one, jak wpisywano temat odbudowy Wrocławia w topos „miasta ruin”, jakim była stolica.

Wspomniana wyżej praktyka dotyczyła całego Śląska, który w XX wieku „podlegał - dowodzi autor - kulturowej kolonizacji, prowadzącej m.in. do instrumentalnej i selektywnej wykładni jego historii i pamięci zbiorowej oraz podporządkowywania mowy, obyczajów i wyznania jego mieszkańców normom ogólnonarodowym" [s. 131]. To samo działo się, dodajmy, w pozostałych polskich regionach, które powstały po wojnie i które również stanowiły „,ziemie obiecane, spustoszone i niczyje”, jak określony został Śląsk w tytule jednego z rozdziałów książki. To ważne zagadnienie, powracające we współczesnych badaniach regionalistycznych, niebezpodstawnie wpisujących się $\mathrm{w}$ humanistykę, którą za Ewą Domańską należałoby nazywać „ratowniczą". Praca Wojciecha Browarnego należy właśnie do tego nurtu.

„Ratowniczemu" nastawieniu nieuchronnie towarzyszyć musi myślenie $\mathrm{w}$ kategoriach pewnej utopii, która retroaktywnie modeluje region jako wielokulturowe „nieskończone pogranicze”, radykalnie otwarte na kulturowy i cywilizacyjny transfer. Utopijny charakter ma również ufundowana na idei „nieskończonego pogranicza" tożsamość regionalna. Autor zdaje sobie sprawę, że jest to wizja idealistyczna, a zarazem taka, która może dziś w dużym stopniu organizować świadomość zbiorową - z tej właśnie możliwości, zauważa, czerpie współczesna twórczość literacka. „Literatura po 1989 roku jest więc w znacznej mierze próbą stworzenia takiej symboliczno-kulturowej przestrzeni, która nie zacierając odmiennych tradycji łączyłaby jego dawnych i dzisiejszych mieszkańców ponad nowoczesnymi podziałami" [s. 131] - pisze Browarny i kształtującej się w ten sposób wyobraźni zbiorowej podsuwa podwójny patronat: Frankensteina i Flinsa. Metafora pozszywanego z różnych kawałków ciała Frankensteina odzwierciedla obraz regionu sztucznie utworzonego z fragmentów zdewastowanych kultur i narodów. Flins natomiast - uważany za słowiańskiego boga śmierci i życia - może być patronem migrantów, którym pomaga oswoić nową przestrzeń. „Ten pierwszy ostrzega, że po katastrofie można wrócić do status quo ante tylko literacko, ten drugi dodaje, że każda zbiorowa tożsamość jest właśnie literacka, opiera się na historiach (narracjach), które można utracić, lecz także opowiedzieć na nowo i odzyskać" [s. 212]. 
Cenne jest tu również stwierdzenie, które pojawia się $\mathrm{w}$ podsumowaniu, że ",[1]iteratura nie musi [...] pielęgnować ani tłumić narodowych fobii i pretensji. Jej rola może być inna, choć równie ważna" [s. 343], może ona bowiem tworzyć nowe literackie dziedzictwo regionu, „w którym niechciane lub zapomniane historie stają się znajome i ważne, a znaki w jego przestrzeni znowu czytelne" [s. 343]. Przywołuję te cytaty, by pokazać, że wartość książki nie sprowadza się tylko do jej walorów poznawczych i że może ona być również lekcją wychowania obywatelskiego, formą "pedagogiki" społecznej.

Historie odzyskane to praca, która wyrasta z pasji poznawania, rozumienia, a także przekształcania regionalnej rzeczywistości. Erudycyjna, wnikliwa, operująca językiem przystępnym dla szerszego (nie tylko dla wywodzącego się z kręgów akademickich) odbiorcy, a przy tym spójna myślowo i ciekawie skomponowana - ilustrująca tezy zawarte we Wprowadzeniu bogactwem przykładów pochodzących z różnych gatunków piśmienniczych, daje szeroki obraz regionalnej twórczości i nawiązuje do najlepszych tradycji pisania o Dolnym Śląsku; ożywia te tradycje duchem nowego regionalizmu i humanistyki ratowniczej.

W zaproponowanym tu ujęciu, nakierowanym na problemy wspólnoty i tożsamości poruszane $\mathrm{w}$ dolnośląskim piśmiennictwie, region na nowo staje się ważny, interesujący. Literatura natomiast, traktowana jako narzędzie budowania regionalnej społeczności, okazuje się istotną częścią jego kulturowego dziedzictwa. Autor przekonująco dowodzi, że nie tylko zapisuje ona i diagnozuje, ale też zmienia i przekształca regionalną świadomość. Pozwala również lepiej rozumieć tożsamość współczesnych mieszkańców Wrocławia i Dolnego Śląska oraz towarzyszące jej paradoksy. Znaczenie książki nie ogranicza się przy tym do roli, jaką spełnia wobec regionalnej wspólnoty. Jej wartość polega także na tym, że porusza ona zagadnienia, które żywo zajmują współczesną humanistykę i powracają w dyskursie publicznym. Uruchamiana $\mathrm{w}$ niej perspektywa regionalistyczna okazuje się pryzmatem uwydatniającym złożoność i nieoczywistość spraw związanych z powojenną polską pamięcią i tożsamością. Dlatego Historie odzyskane mogą być zaproszeniem do szerszej, ważnej społecznie dyskusji.

\section{Bibliografia}

Browarny Wojciech (2019), Historie odzyskane. Literackie dziedzictwo Wroctawia i Dolnego Śląska, Wrocław: Wydawnictwo Uniwersytetu Wrocławskiego. 


\title{
Modelling the Region, Remembering the Place: Wojciech Browarny's Historie odzyskane
}

\begin{abstract}
The article discusses the book by Wojciech Browarny Historie odzyskane. Literackie dziedzictwo Wrocławia i Dolnego Ślaska [Rescued Stories: Literary Heritage of Wrocław and Upper Silesia]. The author of the article presents the concept of "rescuing" the forgotten local history by the writers and scholars based in Wrocław and Upper Silesia. The region regains its cultural importance, and the literature becomes a tool in building regional identity. The article demonstrates that the book is not confined to performing a regional function but is also important in a number of ways. It concerns the heritage of Upper Silesia, which is part of the region and Central Europe. It also belongs to contemporary literary criticism and the recent socially engaged humanities.
\end{abstract}

Keywords: literary criticism, new humanities, new regionalism, regional identity, Upper Silesia 